Юрий Андреевич ЛАБЫНЦЕВ 


\section{СТАТУТ ВЕЛИКОГО КНЯЖЕСТВА ЛИТОВСКОГО ${ }^{1}$}

\section{Аннотация:}

Статья посвящена истории создания и издания Статута Великого княжества Литовского 1588 г. Статут 1588 г. был основным сводом гражданских законов Великого княжества Литовского, Русского и Жемойтского - одного из крупнейших государственных образований в Европе своего времени. Статут 1588 г. действовал вплоть до начала XIX в. и стал самым известным изданием из 5000 книг, изданных в Великом княжестве Литовском за всю его историю.

\section{Ключевые слова:}

Статуты Великого княжества Литовского, Великое княжество Литовское, белорусская литература, восточнославянская книжность, славистика.

\section{Abstract: Y.A. Labuntsev "Statute of the Grand Duchy of Lithuania (1588)".}

The article is devoted to the history of creation and publication of the Statute of the Grand Duchy of Lithuania in 1588. The Statute of 1588 was the main body of civil laws of the Grand Duchy of Lithuania, Russia and Gemoitia: one of the largest state entities in Europe of its time. The Statute of 1588 was in force until the beginning of the 19th century and became the most famous title of the 5,000 books published in the Grand Duchy of Lithuania in its history.

\section{Keywords:}

Statutes of the Grand Duchy of Lithuania, Grand Duchy of Lithuania, Belarusian literature, the East Slavic book culture, Slavic studies.

Статут Великого княжества Литовского 1588 г. - основной свод княжества Литовского, Русского и Жемойтского, своеобразная «конституция» и гарант независимости этой державы, некогда бывшей одной из крупнейших в Европе. Он представляет собой правовой и литературный памятник, вобравший в себя все лучшее из сферы богатейшего кирилломефодиевского наследия этого восточноевропейского государства, которое в основном населяли восточные славяне. Статут служит предметом особой национальной гордости белорусов, литовцев и отчасти украинцев и имеет важное значение для изучения истории старобелорусского языка и литературы. Его создавали в течение десятилетий лучшие умы белорусского народа, а затем он столетиями способствовал сохранению родной культуры.

\footnotetext{
1 Работа выполнена при финансовой поддержке РФФИ (грант № 18-512-76004).
} 
Первый Статут Великого княжества Литовского, содержавший нормы земельного, уголовного, гражданского, процессуального и государственного права, был составлен в 1529 г. и состоял из 13 разделов. Некоторые его положения со временем устаревали и нуждались в исправлении и изменении. В этой связи в 1566 г. была составлена новая редакция Статута, состоявшая уже из 14 разделов. Третий же Литовский Статут увидел свет в знаменитой типографии виленских купцов Мамоничей в 1588 г. Все три издания Статута явились плодом кропотливого труда многих авторов, они представляли собой своего рода коллективные сочинения, которые на протяжении многих лет писались, исправлялись и редактировались. Ведущую роль в составлении каждого из них исполняла специальная комиссия, в состав которой входили различные специалисты. При составлении Статута 1588 г. в назначенную королем комиссию вошло 11 человек православного, католического и протестантского вероисповеданий. Центром деятельности комиссии стала государственная канцелярия, возглавляемая канцлерами и подканцлерами. Делопроизводство в ней тогда велось на западнорусском языке с использованием его старобелорусского и старо-

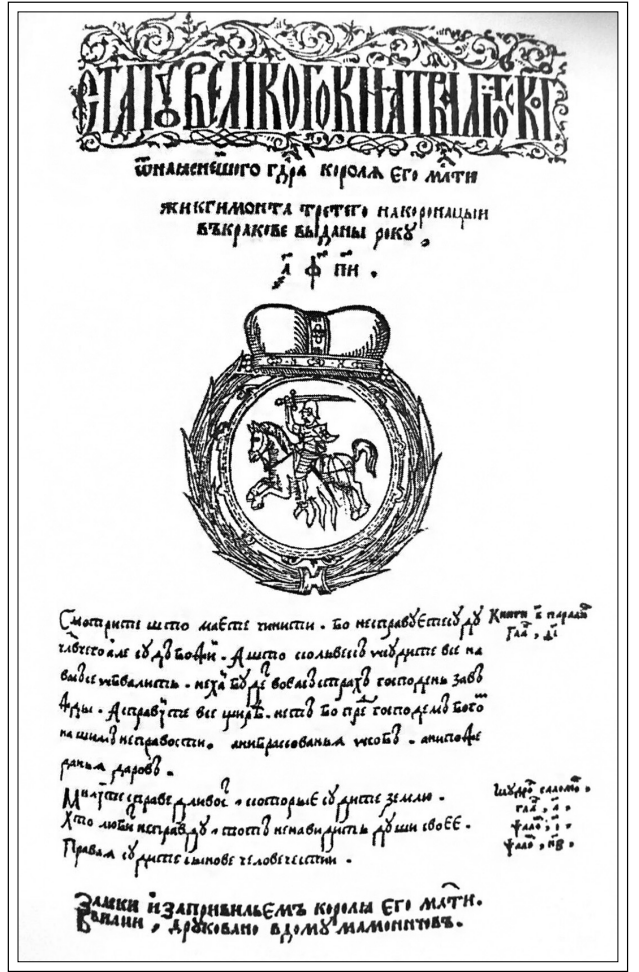

Титульный лист

первого издания Статута

Великого княжества Литовского 15882. украинского диалектов.

При подготовке проекта Статута 1588 г. особую роль сыграли канцлер Остафий Волович, перешедший из кальвинизма в православие, и подканцлер Лев Сапега, ставший в эти годы католиком. Они прекрасно владели местным книжным языком того времени, а приоритет в нем старобелорусской языковой составляющей не подлежал тогда сомнению. Она наша свое отражение во многих положениях Статута 1588 г., закрепив его государственный характер. Известны три отдельные издания текста Литовского Статута 1588 г., имеющие выходную дату «1588», но отличающиеся оформлением титульного листа и его оборота. Единоличное право на издание Статута латинским (польским) и кирилловским («русским») шрифтами король предоставил Льву Сапеге, который пользовался им вплоть до своей кончины в 1633 г. Оригинал Статута, в том числе и его утвержденный королем список, был издан 
на западнорусском языке с использованием старобелорусского и староукраинского диалектов. Польский перевод памятника появился значительно позже, и его качество оказалось не совсем удовлетворительным, поскольку польская терминология того времени не могла отразить все особенности материальной и духовной жизни населения Великого княжества Литовского. Первое польскоязычное издание Статута было напечатано в той же типографии Мамоничей лишь в 1614 г., а втоpoe - в 1619 г.

Литовские Статуты ученые рассматривали вначале сугубо как памятники истории права, по мере более тесного знакомства с ними, их начали воспринимать и как памятники письменной культуры. Особенно это касалось Статута 1588 г., оказавшего существенное влияние на культурные судьбы соседних народов. Он неоднократно переиздавался, разошелся во многих тысячах экземпляров и на протяжении более трех веков служил делу сохранения и утверждению роли белорусского языка и литературы.

Статут 1588 г. стал самым главным и важным изданием из пяти тысяч книг, вышедших в свет до начала XIX в. в Великом княжестве Литовском. Этот памятник старобелорусской литературы наряду с произведениями Франциска Скорины возбудил сильнейший интерес в нарождавшейся в начале XIX в. славяноведческой науке. Все три издания Статута 1588 г., совокупный тираж которых составил около четырех тысяч экземпляров, получили самое широкое распространение в государстве и далеко за его пределами. Он находился в обиходе вплоть до первой половины ХІХ в., судопроизводство по нему, судя по имеющимся пометам, кое-где велось еще в XIX в. Сохранилось несколько десятков рукописных списков Статута 1588 г. Огромный интерес к Этому изданию проявлялся во многих странах мира, со временем большое число его экземпляров оказалось в книжных собраниях знаменитых деятелей культуры, в том числе и русских. Статут 1588 г. по сей день остается важнейшим свидетельством о величии некогда одного из самых могущественных государств Европы. 


\section{ЛИТЕРАТУРА}

Лаппо И.И. Литовский Статут 1588 г. Каунас, 1934-1938. Т. 1-2.

Статут Вялікага княства Літоускага 1588 года: Тэксты. Давед. Камент. / Беларус.

Сав. Энцыкл.; рэдкал.: І. П. Шамякін (гал. рэд.) [і інш.]. Мінск : БелСЭ, 1989. 573 с.

Мякишев В. Кириллические издания Литовского Статута 1588 года. Краков, 2014.

\section{СПИСОК ИЛЛЮСТРАЦИЙ}

1. Титульный лист первого издания Статута Великого княжества ЛитОВСКОГО 1588 г.

2. Титульный лист второго издания Статута Великого княжества ЛитОВСКОГО 1588 г.

3. Титульный лист третьего издания Статута Великого княжества ЛитОВСКОГО 1588 г.

4. Герб Льва Сапеги в первом издании Статута Великого княжества ЛитОВСКОГО 1588 г.

5. Портрет короля Сигизмунда III Вазы во втором издании Статута Великого княжества Литовского 1588 г.

6. Портрет короля Сигизмунда III Вазы в третьем издании Статута Великого княжества Литовского 1588 г.

7. Обращение Льва Сапеги ко всем сословиям Великого княжества Литовского в первом издании Статута Великого княжества Литовского $1588 \Gamma$.

8. Привилегия короля Сигизмунда III Вазы на публикацию в первом издании Статута Великого княжества Литовского 1588 г.

9. Привилегия короля Сигизмунда III Вазы на публикацию во втором издании Статута Великого княжества Литовского 1588 г.

10. Титульный лист второго польскоязычного издания Статута Великого княжества Литовского 1588 г. (Wilno, 1619) 